\title{
PENGARUH KEBIASAAN SARAPAN DAN PENDIDIKAN IBU TERHADAP STATUS GIZI DAN TINGKAT PRESTASI ANAK KELAS IV DAN V DI SD INPRES WEETEBULA II
}

\author{
Ester Verninde, I Gede Mustika, Purwaningtyas Kusumaningsih \\ Program Studi Ilmu Gizi, Universitas Dhyana Pura \\ Email : vhevherninde8583@gmail.com
}

\begin{abstract}
ABSTRAK
Sumber daya manusia (SDM) adalah salah satu factor utama yang diperlukan dalam melaksanakan pembangunan nasional. Dua diantaranya yang berperan penting yaitu factor kesehatan dan gizi. Tingkat prestasi pada anak SD di pengaruhi oleh faktor internal dan eksternal. Tujuan penelitian ini adalah untuk mengetahui pengaruh kebiasaan sarapan, pedidikan ibu dan status gizi terhadap tingkat prestasi anak kelas IV dan V SD Inpres Weetebula II. Desain Cross Sectional yang dilakukan pada bulan Mei-Juni 2018 dengan teknik pengambilan sampel menggunakan probability sampling dengan cara simple random sampling pada siswa kelas IV dan V (37 responden). Data kebiasaan sarapan menggunakan kuesioner, pendidikan ibu menggunakan data sekolah, status gizi menggunakan pengukuran antropometri, sedangkan tingkat prestasi menggunakan nilai raport. Hasil penelitian ini menunjukkan bahwa kebiasaan sarapan pagi terhadap status gizi berpengaruh (nilai $\mathrm{p}=0,000$ ), pendidikan ibu terhadap status gizi tidak berpengaruh (nilai $\mathrm{p}=0,520$ ), status gizi tidak berpengaruh terhadap tingkat prestasi (nilai $\mathrm{p}=0,638$ ), kebiasaan sarapan berpengaruh terhadap tingkat prestasi (nilai $\mathrm{p}=0,044$ ), pendidikan ibu tidak berpengaruh terhadap tingkat prestasi (nilai $\mathrm{p}=0,334$ ). Penelitian ini menunjukkan ada pengaruh antara kebiasaan sarapan terhadap status gizi dan tingkat prestasi dan tidak ada pengaruh antara kebiasaan sarapan, pendidikan ibu dan status gizi terhadap tingkat prestasi.
\end{abstract}

Kata kunci :kebiasaan sarapan, pendidikan ibu, status gizi dan tingkat prestasi. Siswa SD

\begin{abstract}
Human resources (HR) are one of the main factors needed in carrying out national development. Two of them have important roles, namely health and nutrition factors. The level of achievement in elementary school children is influenced by internal and external factors. The purpose of this study was to determine the effect of breakfast habits, maternal education and nutritional status on the level of achievement of grade IV and V children of SD Inpres Weetebula II. Cross Sectional Design conducted in May-June 2018 with a sampling technique using probability sampling by means of simple random sampling for students in grades $I V$ and $V$ (37 respondents). Data on breakfast habits using questionnaires, maternal education using school data, nutritional status using anthropometric measurements, while the achievement level uses report cards. The results of this study indicate that the habit of breakfast to nutritional status has an effect ( $p$ value = 0,000 ), maternal education on nutritional status has no effect ( $p$ value $=0.520$ ), nutritional status does not affect the level of achievement ( $p$ value $=0.638$ ), influential breakfast habits towards the level of achievement ( $p$ value $=0.044)$, maternal education does not affect the level of achievement ( $p$ value $=$ 0.334). This study shows that there is an influence between breakfast habits on nutritional status and level of achievement and no influence between breakfast habits, maternal education and nutritional status on achievement levels.
\end{abstract}

Keywords: breakfast habits, maternal education, nutritional status and level of achievement. Elementary students

\section{PENDAHULUAN}

Sumber Daya Manusia (SDM) adalah salah satu faktor utama yang diperlukan dalam melaksanakan pembangunan nasional. Faktor diantaranya yang berperan penting yaitu faktor kesehatan dan gizi. Orang tidak akan dapat mengembangkan kapasitasnya secara maksimal apabila yang bersangkutan tidak memiliki status gizi yang optimal (Riskesdas, 2013).
Kualitas sumber daya manusia harus ditingkatkan terus menerus sesuai dengan ilmu pengetahuan dan teknologi serta perkembangan nasional. Salah satu upaya yang dilakukan untuk meningkatkan sumber daya manusia adalah melalui pendidikan. Sementara itu pada sisi lainnya keadaan kesehatan dan gizi anak sekolah adalah faktor yang menentukan dalam keberhasilan pendidikan. Gizi menjadi penting bagi anak sekolah karena selain dapat meningkatkan 
kecerdasan anak juga dapat menunjang pertumbuhan secara fisik dan mental. Guna mendukung keadaan tersebut anak sekolah memerlukan kondisi tubuh yang optimal dan bugar sehingga memerlukan status gizi yang baik (Handari, 2005). Anak sekolah dijadikan sebagai subyek dalam penelitian ini dikarenakan anak sekolah termasuk kelompok usia yang rentan gizi. Anak sekolah juga merupakan kelompok masyarakat yang mudah menderita kelainan gizi bila suatu masyarakat kekurangan persediaan bahan makanan (Suharjo, 2003).

Manusia membutuhkan sarapan karena dalam sarapan pagi diharapkan terjadinya ketersediaan energi yang digunakan untuk jam pertama melakukan aktivitas. Khususnya, pada anak usia sekolah dasar (SD), yang dikategorikan masih dalam tahap perkembangan dan pertumbuhan. Energi yang diperlukan untuk belajar sangat bergantung dari asupan gizi yang diperoleh dari makanan yang dimakan. Apabila anak tidak sarapan pagi maka energi yang dibutuhkan untuk berpikir tidak mendukung, dampaknya anak tidak konsentrasi untuk belajar karena perut kosong sehingga berpengaruh terhadap hasil belajarnya .

Tingkat pendidikan ibu erat kaitannya dengan tingkat pengetahuan kebersihan, serta kesadaran kesehatan dan gizi anak-anak dan keluarganya. Tingkat pendidikan turut mempengaruhi mudah tidaknya seseorang memahami pengetahuan gizi yang mereka peroleh. Dari kepentingan gizi keluarga, pendidikan diperlukan agar seseorang lebih tanggap terhadap masalah gizi dalam keluarga (Mastari, 2009).

Di Indonesia prestasi belajar menempati peringkat 121 dari 186 negara di dunia, dimana pendidikan menjadi indikator apakah negara sudah maju atau masih berkembang. Peringkat tersebut menunjukkan bahwa indonesia masuk kedalam kategori negara berkembang (United Nation Development Programme, 2013). Prestasi belajar ditentukan oleh faktor internal dan eksternal (Slameto, 2010).

Rendahnya mutu prestasi belajar sudah lama terjadi pada dunia pendidikan di indonesia. Gejala ini muncul ketika sedang dilakukan pembaruan pendidikan. Berdasarkan studi pendahuluan yang penulis lakukan pada bulan Januari 2018 di SD Inpres Weetabula II Sumba Barat Daya, tercatat bahwa tingkat kenaikan kelas secara keseluruhan mencapai $75 \%$ dari presentase yang diharapkan adalah sebesar $95 \%$ sedangkan untuk tingkat kelulusan mencapai $80 \%$ dari tingkat presentase yang diharapkan sebesar $93 \%$. Adapun faktorfaktor yang mempengaruhi tingkat prestasi menurut Umar (2005), yaitu lingkungan tempat tinggalnya, baik keluarga, masyarakat, maupun sekolah. Semua faktor ini saling berkaitan dan saling berpengaruh satu sama lainnya, dalam peningkatan prestasi belajar anak.

Kebiasaan sarapan yang dilakukan oleh masyarakat sumba barat daya yaitu antara lain: ubi dan teh, nasi campur, roti dan susu. Dalam pemenuhan kebutuhan energi total per hari anak usia sekolah yaitu 1.600-2000 kalori. Sarapan pagi juga dapat membantu tubuhnya agar lebih efisien dalam mengolah makanan sebagai energi, sehingga anak lebih jarang merasa lapar. Menu sarapan sehat untuk anak haruslah terdiri dari 300 gram karbohidrat, 65 gram protein, 50 gram lemak, 25 gram serat, serta asupan berbagai vitamin dan mineral (Hardinsyah, 2014). Berdasarkan hasil penelitian yang dilakukan oleh Triyani (2005), prestasi belajar di pengaruhi oleh kebiasaan makan pagi dan hasil analisis regresi berganda menunjukkan adanya hubungan yang signifikan antara status gizi dengan prestasi belajar. Penelitian lainnya memperoleh bahwa tingkat pendidikan dan budaya dalam keluarga mempengaruhi sikap anak dalam belajar (Nini Subini,2012).

Dari latar belakang permasalahan dan beberapa hasil penelitian di atas, dan karena belum ada penelitian serupa yang dilakukan di Sumba terkait gizi pada anak sekolah, maka peneliti tertarik untuk meneliti mengenai pengaruh kebiasaan sarapan dan pendidikan ibu terhadap status gizi dan tingkat prestasi anak sekolah di SD Inpres Weetebula II Sumba Barat Daya.

Berdasarkan uraian dalam latar belakang masalah di depan, dapat dirumuskan permasalahan penelitian, yaitu bagaimanakah pengaruh kebiasaan sarapan dan pendidikan ibu terhadap status gizi dan tingkat prestasi anak sekolah di SD Inpres Weetabula II ?

Kebiasaan makan anak juga dipengaruhi oleh media massa dan lingkungan (guru, teman sebaya). Makanan yang diiklankan di televisi merupakan makanan yang ingin dicoba oleh anak-anak. Pengaruh teman sebaya cukup besar karena anak lebih banyak menghabiskan waktu dengan teman dibandingkan keluarga. Kebiasaan oarang tua dalam hal makanan sangat berpengaruh terhadap budaya yang membuat anak suka dan tidak begitu suka terhadap makanan. Disamping itu kebersamaan dalam makan bersama keluarga dapat membuat ikatan komunikasi antar keluarga (Sulistyoningsih, 2011).

Susunan hidangan anak usia sekolah terdiri dari makanan pokok, lauk hewani dan nabati, sayur, buah, dan susu. Sedangkan pola makan tiga kali makanan utama dan dua kali sanck di antara waktu makan.

Kebiasaan makan merupakan pola perilaku yang diperoleh dari praktik yang terjadi berulang- 
ulang. Kebiasaan makan adalah suatu suatu perilaku konsumsi pangan yang diperoleh karena terjadinya berulang-ulang. Tindakan manusia terhadap makan dan makanan dipengaruhi oleh pengetahuan, perasaan, persepsi, dan persepsi tentang pangan atau makanan (Suyatno, 2010). Kebiasaan makan dapat pula diartikan sebagai cara individu atau kelompok dalam memilih pangan dan mengkonsumsinya sebagai reakasi terhadap pengaruh fisiologi, psikologi, sosial, dan budaya. Kebiasaan makan adalah seluruh perilaku yang berhubungan dengan makan dan makanan yang mencukupi tata krama makan, frekuensi makana, pola makan, pantangan, distribusi makan di dalam keluarga dan preferensi terhadap makanan dan cara memilih bahan makanan (Pramesthi, 2011).

Kebiasaan makan ada yang baik dan ada pula yang buruk. Kebiasaan makan yang baik adalah kebiasaan makan yang dapat mendorong terpenuhinya kecukupan gizi. Sedangkan kebiasaan makan yang tidak baik adalah kebiasaan makan yang dapat menghambat terpenuhinya kecukupan zat gizi (Kusumaningsih, 2000).

Menurut Jelliffe (1989) dalam Supariasa (2002), status gizi adalah tanda-tanda atau penampilan fisik yang diakibatkan karena adanya keseimbangan antara masuk dan keluarnya zat gizi dalam tubuh yang terlihat melalui variabel-variabel tertentu yaitu melalui suatu indikator status gizi. Status gizi diartikan sebagai keadaan kesehatan fisik seseorang atau sekelompok orang yang ditentukan dengan salah satu atau kombinasi dari ukuran-ukuran gizi tertentu (Soekirman, 2000).

Menurut Almatsier (2006), status gizi adalah keadaan tubuh sebagai akibat konsumsi makanan dan penggunaan zat-zat gizi. Sedangkan zat gizi (nutrients) adalah ikatan kimia yang diperlukan tubuh untuk melakukan fungsinya, yaitu menghasilkan energi, membangun dan memelihara jaringan, serta mengatur proses-proses kehidupan. Berdasarkan Kepmenkes (2010), baku antropometri anak 5-18 tahun dihitung dengan nilai Z- skore IMT/U. Berdasarkan indicator IMT/U, status gizi diklasifikasikan dengan beberapa kelompok, yaitu : Sangat Kurus: < -3 SD. Kurus: -3 SD sampai dengan < -2 SD. Normal: -2 sampai dengan +1 SD. Gemuk: > +1 SD sampai dengan +2 SD. Obesitas: $>+2$ SD

Hipotesis dari penelitian ini adalah ada pengaruh antara kebiasaan sarapan dan tingkat pendidikan ibu terhadap status gizi dan tingkat prestasi pada anak sekolah dasar di SD Inpres Weetabula II. Tujuan umum dari penelitian ini adalah untuk menganalisis pengaruh kebiasaan sarapan dan pendidikan ibu terhadap status gizi dan tingkat prestasi anak sekolah dasar di SD Inpres Weetebula II.

\section{METODE PENELITIAN}

Jenis penelitian yang digunakan dalam penelitian ini adalah observasional yaitu penelitian yang dilakukan dengan cara pengamatan terhadap objek dari variabel-variabel yang diteliti. Rancangan penelitian yang digunakan dalam penelitian ini adalah cross sectional, dimana variabel bebas yaitu kebiasaan sarapan, pendidikan ibu, status gizi dan variabel terikat yaitu tingkat prestasi dikumpulkan secara simultan dan dalam waktu yang bersamaan. Pada penelitian ini metode pengumpulan data dengan menggunakan kuesioner. Kuesioner berisikan pertanyaan mengenai kebiasaan sarapan dan pendidikan ibu. Penelitian ini dilakukan di SD Inpres Weetebula II, jln. Adromeda Sumba Barat Daya pada bulan Mei sampai Juni 2018

Teknik pengambilan sampel yang digunakan dalam penelitian ini adalah probability sampling dengan cara simple random sampling. Adapun besar sampel dalam penelitian ini yaitu 37 orang dan memenuhi kriteria inklusi.

Setelah data terkumpul dari lapangan, selanjutnya dilakukan pengolahan terlebih dahulu (editing dan konversi data) agar data yang tersebar luas dalam item-item kuesioner dapat dibuat lebih ringkas dan lebih sederhana dengan bantuan Program SPSS . Selanjutnya, analisis dilakukan agar data mentah yang didapat dari lapangan mempunyai arti dan makna sehingga dapat menjawab permasalahan yang diajukan.

Teknik analisis diferensial yakni untuk melihat pengaruh di antara variabel-variabel yang tengah diteliti. Untuk tujuan analisis data dan pengujian hipotesis, digunakan taraf signifikansi sebesar 5\%.

Agar sesuai dengan tujuan penelitian, analisis data dilakukan secara kuantitatif untuk menjelaskan dan mendeskripsikan hubungan variabel yang diteliti dengan landasan teori yang dipakai, melalui uraian yang sistematik. Selanjutnya untuk analisis statistik diferensial dilakukan uji hipotesis penelitian dengan menggunakan 'pathanalysis' (analisis jalur).

Alasan menggunakan Path Analysis atau analisis jalur ini, adalah karena dengan alat ini dapat dijelaskan tata hitung antar variabel dan hubungan mana yang perlu diperhitungkan karena dianggap penting. Analisis jalur ini memungkinkan dilakukannya analisis terhadap serangkaian hubungan secara simultan sehingga memberikan efisiensi secara statistik (Ghozali, 2004).

\section{HASIL DAN PEMBAHASAN}

Pengujian data dilakukan dengan analisis jalur (path analysis), yaitu menguji pola 
hubungan yang mengungkapkan pengaruh variabel atau seperangkat variabel terhadap variabel lainnya, baik pengaruh langsung maupun pengaruh tidak langsung.

Pengaruh Kebiasaan Sarapan Terhadap Status Gizi Pada SD Inpres Weetebula II

Tabel 1 Pengaruh kebiasaan sarapan terhadap status gizi

\begin{tabular}{lllll}
\hline Kebiasaan & \multicolumn{3}{l}{ Status Gizi } & \\
\cline { 2 - 5 } Sarapan & Normal & Gemuk & Total & P Value \\
Ya & 23 & 2 & 25 & 0,000 \\
Kadang-kadang & 9 & 0 & 9 & \\
Tidak & 3 & 0 & 3 & \\
\hline
\end{tabular}

Tebel diatas menunjukkan bahwa ada pengaruh kebiasaan sarapan pagi terhadap status gizi yaitu dimana nilai $\mathrm{p}=0,000<0,05$.

Pengaruh Pendidikan Ibu Terhadap Status Gizi Pada SD Inpres Weetebula II

Tabel 2. Pengaruh pedidikan Ibu terhadap status gizi

\begin{tabular}{|c|c|c|c|c|}
\hline \multirow[t]{2}{*}{ Pendidikan Ibu } & \multicolumn{4}{|c|}{ Status Gizi } \\
\hline & Normal & Gemuk & Total & P Value \\
\hline SD & 10 & 1 & 11 & 0,520 \\
\hline SMP & 20 & 0 & 20 & \\
\hline SMA & 3 & 1 & 1 & \\
\hline DIPLOMA & 1 & 0 & 1 & \\
\hline SARJANA & 1 & 0 & 1 & \\
\hline
\end{tabular}

Tebel diatas menunjukkan bahwa tidak ada pengaruh pendidikan ibu terhadap status gizi yaitu dimana nilai $\mathrm{p}$ $=0,520>0,05$.

\section{Pengaruh kebiasaan sarapan Terhadap Tingkat Prestasi Pada SD Inpres Weetebula II}

Tabel 3. Pengaruh kebiasaan sarapan terhadap tingkat prestasi

\begin{tabular}{lllll}
\hline Kebiasaan Sarapan & \multicolumn{4}{l}{ Tingkat prestasi } \\
\cline { 2 - 5 } & Baik & Kurang & Total & P Value \\
Ya & 14 & 11 & 25 & 0,044 \\
Kadang-kadang & 0 & 9 & 9 & \\
Tidak & 1 & 2 & 3 & \\
\hline
\end{tabular}

Tebel diatas menunjukkan bahwa ada pengaruh kebiasaan sarapan terhadap tingkat prestasi yaitu dimana nilai $\mathrm{p}=0,044<0,005$.

Pengaruh pendidikan Ibu Terhadap Tingkat Prestasi Pada SD Inpres Weetebula II

Tabel 4. Pengaruh pendidikan ibu terhadap tingkat prestasi

\begin{tabular}{lllll}
\hline Pendidikan Ibu & \multicolumn{3}{l}{ Tingkat Prestasi } \\
\cline { 2 - 5 } & Baik & Kurang & Total & P Value \\
SD & 5 & 6 & 11 & 0,520 \\
SMP & 7 & 13 & 20 & \\
SMA & 2 & 2 & 4 & \\
DIPLOMA & & 1 & 1 & \\
SARJANA & 1 & & 1 &
\end{tabular}

Tebel diatas menunjukkan bahwa tidak ada pengaruh pendidikan ibu terhadap tingkat prestasi yaitu dimana nilai $\mathrm{p}=0,334>0,05$.

\section{Pengaruh status gizi Terhadap Tingkat Prestasi Pada SD Inpres Weetebula II}

Tabel 5. Pengaruh pendidikan ibu terhadap tingkat prestasi

\begin{tabular}{lllll}
\hline Status Gizi & \multicolumn{3}{l}{ Tingkat Prestasi } \\
\cline { 2 - 5 } & Baik & Sedang & Total & P Value \\
Normal & 13 & 22 & 35 & 0,638 \\
Gemuk & 2 & & 2 & \\
\hline
\end{tabular}

Tebel diatas menunjukkan bahwa tidak ada pengaruh status gizi terhadap tingkat prestasi yaitu dimana nilai $\mathrm{p}$ $=0,638>0,005$. 
Hasil penelitian menunjukkan anak yang jarang sarapan 9 (24,3\% anak) dan tidak pernah sarapan sebanyak 3 (8,1\% anak). Alasan kenapa mereka tidak sarapan karena tidak biasa sarapan dan terlambat bangun dan tidak ada selera makan. Hasil tersebut sama dengan penelitian yang dilakukan Kurnia di SD Negri Padangsari 02 Banyumanik yang menunjukkan hasil masih terdapat $30,4 \%$ anak yang jarang sarapan dan $5,4 \%$ anak tidak pernah sarapan.

Jenis sarapan yang dilakukan subjek yaitu susu dan roti, teh dan ubi, nasi campur, nasi goreng, dan mie instant. Jenis sarapan ini kalau dilihat dari nilai gizinya cukup atau padat energi tetapi ada yang beranggapan bahwa minum susu sudah termasuk sarapan padahal jika jika dilihat dari definisi sarapan adalah makanan yang dimakan pada pagi hari sebelum beraktivitas yang terdiri dari makanan pokok dan lauk pauk atau makanan kudapan dengan waktu sarapan dimulai dari pukul 06.00 sampai dengan pukul 10.00 (Purnakarya, 2010).

Pendidikan ibu terbanyak kategori SMP sebanyak 20 (54\% ibu), SD $11(29,8 \%)$, SMA 4 $(10,8 \%)$, Diploma $1(2,7 \%)$, dan Sarjana 1(2,7\%). Hasil ini menunjukkan bahwa pendidikan ibu sangat rendah namun tidak berpengaruh pada pengetahuan ibu dikarenakan pengembangan teknologi yang ada saat ini.

Hal tersebut didukung oleh pendapat Nurwijayanti (2018) disampaikan bahwa ada hubungan antara pola makan, kebiasaan sarapan dan status gizi dengan prestasi belajar. Pola makan yang baik pada anak dalam jangka waktu yang lama akan berdampak pada status gizi yang baik pula pada anak. Status gizi yang baik menjadi salah satu indikator anak sehat. Pola makan yang baik juga bisa dikatakan bahwa jumlah makan yang dikonsumsi sudah sesuai kebutuhan, jenis zat gizi dalam makanan terpenuhi serta frekuensi/ kuantitas makan yang baik. Dengan pola makan yang baik maka bisa disampaikan bahwa pemenuhan zat gizi anak juga terpenuhi. Zat gizi yang masuk ke dalam tubuh anak menjadi bahan bakar pemenuhan energi dalam melakukan aktivitas keseharian anak. Adanya kebiasaan konsumsi makan yang baik didukung pula adanya kebiasaan anak untuk sarapan pagi, maka memberikan dampak konsentrasi anak juga akan baik. Konsentrasi anak yang baik dalam belajar akan meningkatkan prestasi anak. Demikian pula sebaliknya, konsentrasi anak yang kurang, yang mungkin disebabkan beberapa faktor seperti pola makan yang tidak baik, jarangnya sarapan pagi maka akan berpengaruh terhadap tingkat prestasi.

\section{Pengaruh Kebiasaan sarapan Terhadap Status gizi Pada SD Impres Weetabula II.}

Untuk mengetahui secara lebih rinci pengaruh kebiasaan sarapan pagi terhadap status gizi di SD Impres Weetabula II. Hal ini berarti terdapat pengaruh positif kebiasaan sarapan pagi terhadap status gizi. Besar pengaruh yang diperoleh yaitu $(\mathrm{p}=0,000)$. Angka ini menunjukkan bahwa kebiasaan sarapan pagi memiliki pengaruh signifikan terhadap status gizi.

Ada 3 responden yang tidak sarapan pagi namun status gizinya baik namun harus tetap diperhatikan sarapan paginya karena sarapan pagi sangat penting dan dibutuhkan untuk pertumbuhan dan perkembangan anak usia sekolah. Pengaruh sarapan terhadap status gizi yaitu melalui pemenuhan kebutuhan zat gizi karena sarapan dapat memberikan sumbangan zat gizi perharinya.

Anak yang tidak sarapan maka akan berisiko defisiensi zat gizi. Jika hal ini berlangsung lama akan berpengaruh terhadap status gizinya. Sarapan yang baik akan memberikan sumbangan energi sebanyak $20 \%$. Status gizi yang baik atau optimal akan berpengaruh bila tubuh memperoleh cukup zat gizi yang digunakan secara efisien, sehingga memungkinkan pertumbuhan fisik, pertumbuhan otak, kemampuan kerja otak. Seorang anak yang sehat dan normal akan tumbuh sesuai dengan potensi genetik yang dimilikinya, tetapi pertumbuhan ini juga akan dipengaruhi oleh intake gizi yang dikonsumsi dalam bentuk makanan. Cadangan energi yang rendah dan tinggi lemak akan berdampak pada penurunan produktivitas dan prestasi belajar pada anak sekolah sebagai akibat kekurangan dan kelebihan zat gizi. Kekurangan atau kelebihan zat gizi akan mempengaruhi status gizi anak (Kurnia, 2014).

Hal tersebut didukung oleh pendapat Nurwijayanti (2017) menunjukkan bahwa ada pengaruh kebiasaan sarapan terhadap status gizi yaitu dengan kebiasaan anak sarapan pagi, maka dapat menjamin status gizi anak lebih baik dan memberikan dampak pada konsentrasi anak juga akan baik.

\section{Pengaruh pendidikan ibu terhadap status gizi Pada SD Inpres Weetabula II}

Dalam penelitian ini tidak ada hubungan antara tingkat pendidikan ibu dengan status gizi. Besar pengaruh yang diperoleh yaitu $(p=0,520)$ tidak ada hubungannya dikarenakan perkembangan teknologi yang ada saat ini. Ibu dengan tingkat pendidikan rendah dengan adanya perkembangan teknologi saat ini dapat dengan mudah mengakses informasi dari berbagai media seperti tv, internet, radio, dan penyuluhan dari puskesmas, KEDARSI (keluarga sadar gizi) serta pelacakan gizi buruk 
sehingga mereka dapat meningkatkan pengetahuannya mengenai kesehatan yang baik. Hasil penelitian ini di dukung oleh peneltian Linda (2011) dan Edris (2007), yang menunjukkan tidak ada hubungan antara pendidikan ibu dengan status gizi anak.

Hasil penelitian Kusumaningrum (2003), yang menunjukan adanya hubungan tingkat pendidikan dengan status gizi balita di Kecamatan Simo Boyolali. Pengetahuan yang baik akan mempengaruhi pola konsumsi makanan sehingga akan terjadi status gizi yang baik. Pengetahuan dapat diperoleh dari pendidikan formal maupun informal. Penelitian ini tingkat pendidikan tidak berhubungan dengan status gizi, meskipun pada penelitian lain tingkat pendidikan dapat mempengaruhi status gizi.

\section{Pengaruh Status gizi terhadap tingkat prestasi Pada SD Inpres Weetabula II}

Hasil penelitian ini menunjukkan besar pengaruh yang diperoleh yaitu $(\mathrm{p}=0,638)$ yang berarti tidak ada pengaruh positif status gizi terhadap tingkat prestasi, artinya status gizi tidak mampu mempengaruhi prestasi anak. Hal tersebut didukung oleh pendapat Purba (2010) yang menemukan bahwa tidak terdapat hubungan antara status gizi dengan prestasi belajar berdasarkan indeks IMT/U dan TB/U dalam hal ini tidak terdapat hubungan antara status gizi berdasarkan indeks IMT/U dengan prestasi belajar pada penelitian Purba sejalan dengan penelitian Zulaihah dan Widajanti. Hal ini menyatakan bahwa status gizi berdasarkan indeks IMT/U bukan satu-satunya faktor yang mempengaruhi prestasi belajar anak, karena masih banyak faktor lain yang tidak diteliti dalam penelitian ini seperti, lingkungan, aspek psikologis dan faktor belajar. Seorang siswa yang bersikap conserving (apatis) terhadap ilmu pengetahuan cenderung mengambil pendekatan belajar yang sederhana dan tidak mendalam. Sebaliknya, siswa yang berintelegensi tinggi dan mendapat dorongan positif dari orang tuanya, akan memilih pendekatan belajar yang lebih mementingkan kualitas hasil pembelajaran.

Hasil uji berdasarkan indeks TB/U juga tidak mempengaruhi prestasi belajar. Hasil penelitian ini sama dengan penelitian Mohammad (2011) yang menyatakan tidak ada hubungan bermakna antara status gizi dengan prestasi belajar. Hal ini menyatakan, bahwa prestasi belajar anak tidak hanya dipengaruhi oleh status gizi tapi juga dipengaruhi oleh faktor stimulasi dari orang tua dan sarana yang tersedia.

Pengaruh kebiasaan sarapan pagi terhadap tingkat prestasi Pada SD Impres Weetabula II
Hasil penelitian ini menunjukkan bahwa besar pengaruh yang diperoleh yaitu $(\mathrm{p}=0,044)$, yang berarti terdapat pengaruh positif kebiasaan sarapan pagi terhadap tingkat prestasi. Besar pengaruh yang diperoleh adalah 0,385. Angka ini menunjukkan bahwa kebiasaan sarapan pagi memiliki pengaruh signifikan terhadap tingkat prestasi sebesar 38,5\%, sedangkan $61,5 \%$ dipengaruhi oleh faktor di luar. Berpengaruh signifikan dapat diartikan bahwa apabila kebiasaan sarapan ditingkatkan maka dapat semakin meningkat tingkat prestasi. Dalam penelitian ini ada 3 anak yang tidak pernah sarapan pagi namun tingkat prestasinya sedang dan baik dan status gizinya baik dikarenakan anak tersebut makan nasi bungkus/kuning dengan energi \pm 500 kkal pada saat jam istirahat disekolah.

Hal tersebut didukung pendapat Purnakarya (2010) bahwa ada pengaruh kebiasaan sarapan terhadap tingkat prestasi, sebab apabila kekurangan zat gizi akan mengurangi konsentrasi belajar responden. Kekurangan zat gizi akan berdampak pada aktifitas responden di sekolah seperti lesu, mudah letih/lelah, hambatan pertumbuhan, kurang gizi pada masa dewasa dan penurunan prestasi. Adapun penlitian lain yang menunjukan bahwa kebiasaan sarapan pagi tidak mempengaruhi tingkat prestasi anak di SD Muhammadiyah 16 Surakarta ( Wijayanto, 2014) karena prestasi belajar tidak hanya dipengaruhi oleh kebiasaan sarapan saja namun dapat dipengaruhi oleh faktor lain, seperti malas dalam belajar dan lingkungan tempat tingal.

\section{Pengaruh pendidikan ibu terhadap tingkat prestasi Pada SD Inpres Weetabula II}

Hasil penelitian ini menunjukkan bahwa besar pengaruh yang diperoleh yaitu $(\mathrm{p}=0,334)$, yang berarti tidak terdapat pengaruh pendidikan ibu terhadap tingkat prestasi. Artinya pendidikan ibu yang semakin baik belum mampu mempengaruhi tingkat prestasi. Pendidikan orang tua (Ibu) 3 orang anak yang tidak pernah sarapan pagi dalam penelitian ini yaitu SMP (Sekolah Menengah Pertama) namun pendidikan ibu tidak mempengaruhi Status gizi maupun tingkat prestasi anak karena dalam penelitian ini status gizinya baik dan tingkat prestasinya sedang dikarenakan anak tersebut yang malas dalam belajar.

Hal tersebut didukung oleh pendapat Nurhidayah (2008) yang mengatakan bahwa tidak ada pengaruh antara pendidikan ibu maupun pekerjaan terhadap tingkat prestasi anak. Namun dalam masa pertumbuhan dan perkembangan anak harus tetap dalam pantauan orang tua karena sebagian pola asuh anak berasal dari orang tua.

\section{SIMPULAN DAN SARAN}


Berdasarkan hasil penelitian yang telah diuraikan pada bab sebelumnya, maka dapat disimpulkan sebagai berikut : Kebiasaan sarapan mempunyai pengaruh yang positif dan signifikan terhadap status gizi. Pendidikan ibu tidak berpengaruh positif terhadap status gizi. Status gizi tidak berpengaruh positif terhadap tingkat prestasi. Kebiasaan sarapan berpengaruh positif terhadap tingkat prestasi. Pendidikan ibu tidak berpengaruh terhadap tingkat prestasi jadi kebiasaan sarapan dan pendidikan ibu berpengaruh terhadap status gizi serta dampaknya terhadap tingkat prestasi. Berdasarkan simpulan penelitian dapat disampaikan saran-saran sebagai berikut :

Bagi orang tua diharapkan mempunyai peranan yang tinggi dalam mendukung kebiasaan sarapan pada anak, selain itu harus mampu mendidik anak untuk meningkatkan tingkat prestasi Bagi Manajemen Puskesmas bidang promosi kesehatan agar lebih memperhatikan dalam melakukan pemantauan tingkat pemenuhan gizi anak selolah. Diharapkan bagi peneliti selanjutnya agar dapat melakukan penelitian lebih lanjut mengenai umur, jenis kelamin, yang dapat mempengaruhi status gizi dan tingkat prestasi anak.

\section{DAFTAR PUSTAKA}

Ghozali Imam. 2004. “ Aplikasi Analisis Multivariate Dengan Program SPPS". Semarang. Badan Penerbitan Universitas Dipenogoro.

Ghozali Imam. 2016. Aplikasi Analisis Multivariate Dengan Program IBM SPSS22. Semarang: BPFE Universitas Diponegoro.

Kusumaningrum N.R., dan Wiyono V.H., Pengaruh Tingkat Pendidikan Ibu, Aktivitas Ekonomi Ibu dan Pendapatan Keluarga Terhadap Status Gizi Balita di Kecamatan Simo, Kabupaten Boyolali, JPP; 3 (2):105 125, 2003.

Nurwijayanti. 2018. Pola Makan, kebiasaan Sarapan dan Status Gizi Berhubungan Dengan Prestasi Belajar Siswa SMK di Kota Kediri. Jurnal Care Edukasi. 6(1) : 60-61.

Riset Kesehatan Dasar. 2013. Laporan Riset Kesehatan Dasar 2013.

Slameto. 2010. Belajar dan faktor-faktor yang Mempengaruhi. Jakarta. PT. Rhineka Cipta

Suhardjo. 2003. Berbagai Cara Pendidikan Gizi. Edisi 1. Cetakan 1. Bumi

UNDP, 2013. International Human Development Indicators.http://hdr.undp.org 